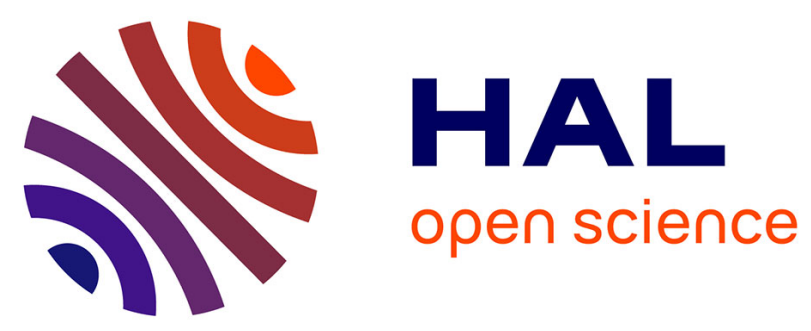

\title{
Storm water management as a public good provision problem: survey to understand perspectives of low-impact development for urban storm water management practices under climate change
}

\author{
C. Carlson, O. Barreteau, P. Kirshen, K. Foltz
}

\section{To cite this version:}

C. Carlson, O. Barreteau, P. Kirshen, K. Foltz. Storm water management as a public good provision problem: survey to understand perspectives of low-impact development for urban storm water management practices under climate change. Journal of Water Resources Planning and Management, 2015, 141 (6), pp.04014080. 10.1061/(asce)wr.1943-5452.0000476 . hal-01301154

\author{
HAL Id: hal-01301154 \\ https://hal.science/hal-01301154
}

Submitted on 11 Apr 2016

HAL is a multi-disciplinary open access archive for the deposit and dissemination of scientific research documents, whether they are published or not. The documents may come from teaching and research institutions in France or abroad, or from public or private research centers.
L'archive ouverte pluridisciplinaire HAL, est destinée au dépôt et à la diffusion de documents scientifiques de niveau recherche, publiés ou non, émanant des établissements d'enseignement et de recherche français ou étrangers, des laboratoires publics ou privés. 


\title{
WR1494
}

\section{Stormwater Management as a Public Good Provision Problem:Survey to Understand Perspectives of Low-Impact Development for Urban Stormwater Management Practices under Climate Change}

Cynthia Carlson, PE, Ph.D., M.ASCE${ }^{1}$; Olivier Barreteau, Ph.D. ${ }^{2}$;Paul Kirshen, Ph.D. ${ }^{3}$; and Kim Foltz ${ }^{4}$

${ }^{1}$ Environmental Science Department, New England College, 98 Bridge Street, Henniker, NH 03242, Office phone: 603-428-2272, Fax number:603-428-3155(Corresponding Author)Email: ccarlson@ nec.edu

${ }^{2}$ IRSTEA, UMR G-EAU, 361, Rue J.-F. Breton, 34033 Montpellier Cedex 1, France

Office phone: +33-4-67046300, Fax number: +33-4-67635795, Email: olivier.barreteau@irstea.fr

${ }^{3}$ Environmental Research Group of Department of Civil Engineering and Institute for the Study of Earth, Oceans and Space, University of New Hampshire, 35 Colovos Road, Gregg Hall, Durham, NH 03824, Office phone:603862-4637, Fax number: 603-862-3957,Email: Paul.Kirshen@unh.edu

${ }^{4}$ Community Building and Environment, Neighborhood of Affordable Housing, 143 Border Street, East Boston, MA, 02128, Office phone: 617-567-5882, Fax number: 617-567-7563, Email: Kim@ @oahcdc.org

\begin{abstract}
Managing urban stormwater is challenging under the best of situations, and due to projected increases in intensity of rainfall events is exacerbated by climate change. Institutional and individual aspects of urban stormwater management and the implications for low impact development (LID) are then presented. The paperframes stormwater as a "public good provision" issue in order to buildon existing knowledge about that kind of social dilemma. This topic is then examined in more detail through stakeholder interviews conducted in Somerville, Massachusetts, USA. Interviews were completed at a variety of management levels, from household to regional planning level, and are related back to the theory of public good provision. Finally, synthesis of theory and practice results in specific recommendations for urban stormwater management, based on revising thestormwater institutional framework, showcasing redevelopment opportunities, and facilitating education and awareness through local NGOs.
\end{abstract}

Keywords: Stormwater runoff, Sustainable urban water management, Low Impact Development (LID), Climate Change, Public Good Provision, Somerville, Survey Results 


\section{Introduction}

Communities all over the world recognize that managing urban stormwater is challenging under the best of conditions. Water quality issues, includingoil, heavy metal, and salt contamination, and quantity issues, allderive from increasing impervious surfaces. Projected increases in intensity of rainfall events due to climate change may exacerbate these challenges. Methods to understand stormwater management have been explored (Pahl-Wostl, 2007; Brown,2005; Koo et $a l, 2012)$. However, traditional ways of viewing stormwater still emphasize individual or municipal/governmental management of stormwater, and generally treat stormwater as a simple waste product to be removed as quickly as possible. These ways of viewing stormwater deemphasize some of its characteristics, such as the tendancy for downstream users to be impacted more severely by stormwater issues, and for upstream users' actions to be more impactful. Traditional ways of understanding stormwater also make it difficult to conceive of how knowledge about and acceptance of new stormwater management techniques might pass between individuals, and how social connections might be used to increase acceptance and use of stormwater management techniques.

Increased acceptance and use of decentralized stormwater management techniques by homeowners at their own scale may save municipal governments from difficult expenditures, or from having to address damage from stormwater. If homeowners can be helped to recognize the benefit of implementing effective stormwater management, the need for expensive government solutionsor regulations may be reduced. Further, if homeowners educate each other about the practical impacts of improved stormwater management, this mayalso decrease therequirement for local government to act, may reduce overall flooding, and may empower decentralization and improved efficiencies. Relevance to the public and adaptation to local context are key factors in increasing diffusion of alternative techniques for stormwater management (Morison and Brown, 2011). However, how this might occur and how this might be fostered in practice have not been investigated in detail.

To this end, this paper introduces a well-accepted concept from other fields and applies this concept to stormwatermanagement. "Public good provision" is aconceptthat will help identify elements for improved stormwater managementto benefit a community. This leads to an investigation of how communities can invest and work together to manage stormwater. First, we discuss a general background of stormwater management techniques, including present challenges to stormwater management and current ways to address these, such as Low Impact Development (LID), and stormwater management issues projected to be compounded due to climate change. Part two of the paper introduces the concepts of Public Good Provision (PGP), and discusses how these concepts can be applied to better understand stormwater management as a whole. Part three summarizes surveys completed in Somerville, MA regarding stormwater management that give some hints as to the implementation of theory in the field. Finally, part four details recommendations for how theory from public good provision research can be used to improve stormwater management in real cities such as Somerville, Massachusetts.

\subsection{Background}

\subsection{Urban Drainage Challenges}

Drainage systems to manage stormwater runoff are a major component of urban infrastructure. Traditional approaches to stormwater management divert the runoff into open channels or closed 
conduits which discharge into water bodies, removing the water as rapidly as possible. This paradigm impacts both hydrology and water quality; the quality of urban runoff can approach that of untreated human sewage, especially for total suspended solids and nutrients (Metcalf and Eddy, 2002). These conventional approaches are a primary cause of urban catchment degradation (Walsh et al., 2012). Thus even if infrastructure is in perfect condition, urban runoff transmitted directly through the system to surface watersresults in contamination.

In addition, when drainage systems fail or are undersized for a given storm, flooding may result in extensive property damage as well as public health, hydrologic/erosion, and water quality problems. As stormwater infrastructure ages, these problems will grow (NAE, 2009; ASCE 2013).

In older cities, sanitary sewer lines and storm drains are often combined. Under low runoff conditions, these "combined sewers" transmit the runoff together with sanitary sewage to the wastewater treatment plant, resulting in improved water quality. However, under wet weather conditions, water in excess of system capacity can result in combined sewer overflows or CSOs - raw sewage mixed with rain water discharging directly into surface water bodies.

These potential impacts demonstrate how crucial it is thatlocal policy makers, such as municipalities in the US or Communauté de Communes in France,properly manage stormwater in urban areas. In recognition of this for example, national governments are modifying the regulations related to stormwater management: the US government has placed urban areas under increased regulatory pressure to better manage stormwater, with programs designed to require improvements to both quality and quantity of stormwater, for example, the EPA's National Pollutant Discharge Elimination System (USEPA, 2012); the French government has entitled local governments to levy taxes on land owners on the basis of impervious areas (CGCT, 2011).

\subsection{Low Impact Development}

Newer approaches to stormwater management attempt to more closely mimic natural hydrologic systems, attenuating runoff volumes and peak flows. Known as Low Impact Development (LID), these techniques strive "to manage stormwater as close to its source as possible... preserving and recreating natural landscape features, minimizing effective imperviousness to create functional and appealing site drainage that treat stormwater as a resource rather than a waste product" (USEPA, 2013). LID techniques are also effective in reducing the pollution loads from runoff and may have added aesthetic and recreational benefits. LID can be more cost effective than conventional techniques (USEPA, 2013; Roseen et al, 2011). Their efficiency in reducing runoff has been shown to be significant in new neighbourhood development, when using Land Suitability Analysis (Wang et al., 2010).

LID techniques include (USEPA, 2013):

- Conserving open space (including cluster development, open space preservation, reduced pavement widths, shared driveways, and reduced setbacks (shorter driveways)); - Increasing infiltration (including infiltration basins and trenches, porous pavement, disconnected downspouts, rain gardens and other vegetated treatment systems); 
- Storing Runoff (including parking lot, street, and sidewalk storage, rain barrels and cisterns, depressional storage in landscape islands and in tree, shrub, or turf depressions, green roofs, and underground storage in vaults);

- Altering Runoff Conveyance (including eliminating curbs and gutters, creating grassed swales and grass-lined channels, roughening surfaces, creating long flow paths over landscaped areas, installing smaller culverts, pipes, and inlets, and creating terraces); and - Low Impact Landscaping (including planting native, drought tolerant plants, converting turf areas to shrubs and trees, reforestation, encouraging longer grass length, planting wildflower meadows rather than turf along medians and in open space, and amending soil to improve infiltration).

Given the many added benefits of these practices under stable climate conditions or climate change (Grimm et al, 2008), LID may be among the most promising alternatives for storm water management. Conventional approaches are generally designed for single large storms, such as 10- or 100-year events, but do not have the water quality benefits of LID. LID techniques also provide more open, green space in communities, aid in green house gas mitigation, and provide other socialand environmental benefits, such as reduced Urban Heat Island effect, better air quality, and higher property values.

Unfortunately, implementation of these techniques has not been widespread. Not only are there extra technical and construction obstacles to be overcome in heavily developed areas, there are also institutional and social challenges due to the nature of stormwater itself.

\subsection{Climate Change Impacts and Adaptive Planning}

Present and future management of urban runoff is made more complex by projected long-term anthropogenic climate change. The Intergovernmental Panel on Climate Change (IPCC) and others report that increased precipitation and extreme events are expected in most regions of the world (Bates et al, 2008; USGCRP, 2009). Using frequency analysis of daily data from Generalized Circulation Models, Kharin et al (2007) predicted changes in the amount of precipitation for the 20-year, 24-hour storm. The multi-model median showed 5 to 10 percent increases by mid century, and 10 to 15 percent or greater increases by end of century over the continental USA. Using a similar method, Powell (2008) developed plausible scenarios of the extreme design precipitation for the Somerville Massachusetts case study area using the Special Report on Emission Scenarios (SRES, Nakicenovic and Swart,2000) of B1, A1b, and A2 and the output of 20 General Circulation Models (GCM). Median increases to the 10-year, 24-hour storm in 2100 were projected to bebetween $10 \%$ and $15 \%$.

With similar changes occurring around the world, many current stormwater collection systems, already undersized and stressed by existing conditions, are not equipped to handle these changes (NAE, 2009; Semadeni-Davieset al, 2008) and additional capacity is required to deal with this increased excess of water (Hamin and Gurran, 2009). In addition, models indicate that populated river basins all over the world will experience discharge changes (Palmer et al, 2008), resulting in an increased sense of urgency to not only address stormwater management but to operationalize how best to manage water resources. 
Climate change calls for a paradigm shift in stormwater management (Milly et al., 2008, PahlWostl et al., 2007). The current method of simply collecting and draining water as quickly as possible may reach the limits of sustainability. Due to their larger proportion of impervious surfaces, urban areas in particular will experience greater flooding and greater need for improved stormwater management (Ashley et al., 2005). Urbanized coastal areas, such as New England and Greece, are particularly vulnerable (Kirshen et al., 2008; Bosello et al., 2012). Updating infrastructure is costly, especially in urban environments. However, finding funding to maintain existing stormwater infrastructure is difficult (ASCE, 2013), constructing purposefully oversized stormwater conveyance or treatment to prepare for uncertaintieswould be even more challenging for communities to approve and fund, even if a potential alternative is to suffer even more costly damage. Besides, the crowding and chaos of networks and infrastructure currently residing under urban streets often leaves minimal space for expandingpipe diameters or adding new infrastructure.

The uncertainty of the future climate is a major challenge of proactive adaptation planning for stormwater management (WERF, 2009). However, climate uncertainty is far from the only challenge, to this is added population growth, land use change, and technological innovation.

Therefore, stormwater management planning requires developing actions that are robust over time and space (functions acceptably well under all future uncertainties and risks), integrated in urban planning (Cettner et al., 2013) and/or flexible and adjustable (implemented as biophysical and socioeconomic conditions change). Planning should (Kousky et al., 2010; Stakhiv, 2011; Brekke et al., 2009; Lempert and Groves, 2010; NRC, 2009; Yohe, 2009):

- include no-regret (valuable even without climate change) and co-benefit (valuable to multiplesectors) actions, such as green roofs that decrease runoff and increase air quality meanwhile (Mees et al., 2013);

- be integrated with sustainability planning to respond to other pressures on the region, greenhouse gas (GHG) mitigation, and a portfolio of approaches for multiple levels of safety;

- be evaluated with multiple social, economic, and environmental criteria;

- respect equity and adaptive capacity needs;

- be adaptable to a host of future potential weather conditions and climate scenarios; and

- employ adaptive management as needed.

Additionally, besides major decision-makers alreadyinvolved, local stakeholders must be integrated into the planning process in order to better take into account their goals and values, and to plan for better implementation and long-term management(Redmond, 2003) Plans should include actions meant to frame or orient local stakeholders' behavioral patterns, integrating these into the planning process to increase the efficiency of these actions.

There are two types of plans in an adaptation strategy.

- "Here and Now" actions, for new projects or presently threatened areas, should include climate change adaptation in the initial design. Incremental construction costs are relatively low compared to retrofit costs under the present climate.

- In "Prepare and Monitor" actions implementation does not take place now because uncertainties are too high and/or present threats are low - but options are preserved and 
actions taken when a trigger point or threshold, determined as part of the adaptation planning process, is reached (Douglas et al., 2013; Brekke et al., 2009).

Low Impact Developmenttechniques areimportant candidate toolsforclimate change adaptation planning. They can overcome constraints for main infrastructure development such as the need for space and high costs from local authorities. These techniques can be included as part of a flexible, adaptable plan with many co-benefits. As urban stormwater management in many areas could use immediate improvements, LID techniques can be fitted into no-regrets and here-andnowtype actions. LID can also be targeted for expansion or alteration as required to address action plan "prepare and monitor" trigger points, such as those associated with increasing rainfall, increased population, land use changes, and more. LID is flexible, can be developed as necessary, can be quite cost effective (Saravanapavan et al., 2013), and can be easily combined with other stormwater management techniques to form a comprehensive regional and local strategy.LIDs can also generate benefits regarding other urban water managementissues, such as water availability (Walsh et al., 2012).However LID implementation requires the active involvement of a large number of property owners, raising new difficulties.

\subsection{Institutional Challenges}

Although stormwater management is generally seen as a local management issue, municipalities do not generally invest significantly in stormwater unless local residents and businesses directly need drainage management (Welty et al, 2007; Adger et al, 2005). Even when efforts are made, effective management is difficult because of:

- limited available funding,

- drainage not being perceived as a key municipal service, such as trash collection,

- stormwater management being spread among various departments with lack of coordination and limited land use management responsibilities,

- difficulty in developing a comprehensive view of stormwater management issues involving governmental, business and private land owners (Welty et al, 2007; Parkinson, 2003), and

- interjurisdictional network of infrastructure causing downstream impacts based on management practices of upstream municipalities.

Stormwater utilities or partnerships can help address these challenges. Through a stormwater utility, user fees offset costs associated with managing and implementing regional stormwater quality and flow management (Welty et al, 2007). For instance, some utilities charge land owners by the amount of impervious surface; fees increase as owners pave more land. Stormwaterutilities allow users to internalize some of the external costs of increased paving. Some utilities have been successfully implemented, while other areas have found the process politically daunting (Bowen, 2003; American City \& County, 2007.). Education and outreach to residents is considered a priority in successfully developing a utility as a funding source (Brisman, 2001).Another approach is watershed partnerships or specific stormwater management institutions, as in Cleveland, Ohio (Hardy and Koontz, 2010), that support municipalities indevelopingeffective ordinances for stormwater management. Such partnerships 
can increase interaction, providing a framework for municipalities to communicate technical issues to residents and, in turn, for residents to communicate their constraints to policy makers.

LID can be implemented on public or private land. For example, a local or regional authoritymay implement LID in public-owned parking lots.Local governments and states could mandate drainage standards for new development. It is more difficult to mandate or encourage individuals to implement LID for existing development. In all cases, proper implementation requires support from individual stakeholders.

\subsection{Stormwater Management as a Public Good Provision issue}

In this section, we will investigate the ways in whichliterature about public good provisions and similar social dilemmascan informinstitutional issues raised by LID development for stormwater management. The public generally sees benefits from 'public goods,' and those who pay for the upkeep or the provision cannot keep others from also benefiting (low excludability), but these additional benefiters do not reduce the benefits received by all (low subtractability). However, these goods are not gifts and need effort to be produced and/or maintained. Examples of public goods include clean air, street lighting, and fireworks displays. The common issue with public goods is then related to decay due to too low a level of provision and maintenance because no one feels incentive to contribute.

Stormwater management to protect against floods due to excess stormwater runoff fits the characteristics of public goods, including low excludability and low subtractability (Ostrom et $a l ., 1994)$. The population concerned about a watershed receives benefits when infrastructure is constructed toefficiently reducecontribution of a piece of land to runoff: includingeither lesser flood riskor a lesser need to contribute to runoff reduction. It is difficult to sort out this population and protect only those who contributed monetarily to the infrastructure construction. Protection then is not directly dependent on the population concerned; a stakeholder who profits from flood protection does not impact another stakeholder's protection. This is low subtractability. In addition, without actionable regulations, it is difficult to penalize an individual practice contributing to increased runoff. This is low excludability. Thus stormwater management provided through public infrastructure, including protection of community against flood, is a kind ofpublic good.While encouraging the use of LID, the regulations governing stormwater management in Massachusetts, our case study area, provide no mechanismsfor addressing these issues (MEEA, 2008).

In stormwater management, obtaining support from individuals for proposed investments can be difficult because collective action is necessary and free-riding is easy and tempting: since investments in LID take place at plot level costs are primarilyindividual (at land owner level)whilebenefits are collective. Stormwater management with LID techniques is then a typical social dilemma characterized by distributed provision of a public good, since the entire concerned population can potentially contribute. Hence, the scope of possible individual costs increases along with the possibilities for free-riding. These types of social dilemmas have been extensively analysed through experimental and institutional lenses(Ostrom et al., 1994; Janssen and Ahn, 2006). 
Considering water management as a social dilemma is not new. Many pioneering works on social dilemmas deal with water management, such as irrigation (Ostrom, 1992) or drinking water supply (Blomquist, 2001). More recently, water quality has been analysed with this conceptual framework as well (Sarker et al., 2008).

Stormwater management infrastructure has been less considered as a social dilemma, unless as a part of a whole water system (van de Meene et al., 2011). The individual landowner may deny the impact that his or her property has on the quality and quantity of stormwater in the area, or may believe that impact to be negligible. This problem is compounded by the usual practice of stormwater management being funded by the general tax base, resulting in invisible costs and few incentivesfor individual action. LID techniques allow revision to this usual practice because managementis not solely provided at a collective level,funded only by taxes, but also by each land owner's individual action

Even though aninstitutional setting to prevent free riding and to generate benefits for the whole community has to be tailored to context, examples coming from other places and times can help the search for solution to the social dilemma ofstormwater management with LIDs. There is no $a$ priori solution. A recent meta-analysis of urban water management case studies in Australia completed by expert interviews showed a trend towards hybrid governance including hierarchical, market, and network components (van de Meene et al., 2011). Another recent comparative analysis focusing on green roof adaption in cities put hierarchical arrangements at a higher level (Mees et al., 2013), mainly for framing the conditions of development and for ensuring fairness and stability. Interactive arrangements are reported in one case with a utility to promote the innovation.

A meta-analysis of several long enduring common pool resource management case studies (Ostrom, 1990), reveals some basic principles required for effective common pool resource (CPR) management, another type of social dilemma.Butmany of these principles are not relevant for public good provision, like flood protection, and public goods are reported to be a more difficult social dilemma than CPR management (Sell and Son, 1997).

Greenaway et al(2006) suggest that the 'norms of practice and knowledge development' of the public can strongly influence stormwater management. Norms influence stormwater management not only indirectly, through influence on local officials, but also directly through residents' own individual on-site stormwater management practices. In this way, stormwater management shares common features with littering: contribution to the common good is through limiting one's production of either runoff or litter on the public space. Recent studies on littering have shown that environmental participation and membership in environmental organization increase anti-littering behaviour (Torgler et al., 2008).Encouraging active stakeholder participation in environmental organizations or in planning could be an answer.

An example of local and regional stormwater management, framed as a public good, may serve better than pure theory or analogy to illuminate the benefits of framing stormwater management in this way.

\subsection{Case Study 3.1 Case Study Background}


As discussed above,stormwater management can be challenging. There are, however, possibly effective responses to the challenges. To investigate these responses, researchers must first understand how local officials and residents think about LID under present climates, and then project how they might feel under changed climates. The next section addresses these issues in the context of Somerville, Massachusetts, USA providinga case study on how theory actually plays out in a community. The datawill have the secondary benefit of helping municipalities examine the possible roles of LID in present and future local stormwater management.

Somerville is located in eastern Massachusettsneighboringthe cities of Medford (to the north and east), Cambridge (to the west), and Boston (to the southeast). The Mystic River, a tidal waterway up to the Amelia Earhart Dam by Somerville's Assembly Square, forms a portion of the city'snorthern boundary. Alewife Brook forms a portion of the western boundary. Portions of Somerville are within one mile of Boston Harbor on the Atlantic Ocean.

The climate of Somerville is similar to other places in mid-New England, although somewhat tempered by proximity to the ocean. The annual average precipitation is approximately 42.5 inches per year. Average monthly precipitation is fairly constant month-to-month, between 3 inches and 4 inches per month. Precipitation may fall as snow during the winter.

Somerville is a very densely developed urban area. The City is 75,754in population (US Census, 2010), and approximately four square miles in area - resulting in an average population density nearly 19,000 people per square mile. This makes Somerville the most densely populated community in New England (Somerville, 2009).

The City's history of urbanization has resulted in approximately $73 \%$ of the city's surfaces being impervious (Deshpande and Roden, 2005), a very high percentage even for a dense urban area and a significant challenge for stormwater management. In addition, Somerville is a combined sewer community, with stormwater and sanitary sewage sharing pipes in many locations (Figure 1). Stormwater runoff and combined sewer overflows (CSOs) are challenges to the water quality in the Mystic River, a highly valued local resource (Somerville, 2007) with boating, canoeing, hiking, biking, and birding opportunities.

A significant percentage of the population is composed of recent immigrants and/or lower income persons. According to the American Community Survey (US Census, 2010a), in Somerville, $32.6 \%$ of the population speaks a language other than English at home, $26.8 \%$ are foreign born,and $14.7 \%$ of families live below the poverty line. This increases challenges related to building community and communicating with residents. Despite the significant language and cultural diversity, the City works hard to maintain effective public input and access to local government (Somerville, 2009). For example, in February 2014, the City of Somerville advertised for a new director for the Mayor's Office of Sustainability and Environment (OSE), including tasks such as "optimizing the City's potential for recycling, energy efficiency, waste reduction, greenhouse gases emission reduction, and food composting," and making the City "a place other cities look to for ideas on how to combat climate change and curb the wasteful use of resources."

Our case study site is the Winter Hill neighborhood and the commercial Assembly Square area, which are serviced by the combined sewer system of the Somerville-Medford Branch Sewer (S- 
MBS, Figure 1). We chose this site because the Somerville City Engineer identified this area as already experiencing negative impacts due to climate, i.e., local drainage flooding and combined sewer overflows increasing to the Mystic River. The conveyance system has the capacity to handle the wastewater flow but is "only sufficient to handle storm flows resulting from about a one-year storm" (CDM, 1974). A storm that occurred on July 10, 2010 in Somerville dropped approximately $9 \mathrm{~cm}$ of rain in an hour which caused combined sewage to surcharge into the streets. One woman needed to be rescued from a highway underpass near Assembly Square because the water rose too quickly for her to drive out of the tunnel (CNN, 2010).

In addition to the wastewater and stormwater generated in the Winter Hill area, sanitary flow and stormwater also enters the S-MBS from several other neighborhoods bordering the area. The Winter Hill and Assembly Square watersheds draining to the S-MBS cover a total area of 2.7 square kilometers. A number of the contributing watersheds have separate infrastructure for stormwater and sanitary sewage; however, all separated stormwater in the watershed drains into the S-MBS. A separate stormwater outfall was never built due to financial constraints.

Under low flow conditions, S-MBS storm water and combined sewage flow to the Chelsea Creek Headworks and subsequently the Deer Island Wastewater Treatment Plant through the DeLauri Pump Station (Figure 1). Under high flow conditions, excess flow is diverted through the Somerville Marginal Combined Sewer Overflow (CSO) facility, triggering an overflow into the Mystic River. The Somerville Marginal Facility is gravity-operated, unmanned and has a capacity of $11 \mathrm{~m}^{3} / \mathrm{s}$ (245 million gallons per day). Water flowing through the facility is screened and chlorinated and then is discharged into the Mystic River via one of two outfalls depending on the tidal elevation. During low tide, flow discharges through the Outfall 205 (located downstream of the Amelia Earhart Dam) and, during high tide, flow discharges through Outfall 205A (located upstream of the dam).

The USEPA regulates stormwater discharge from urbanized areas through the National Pollutant Discharge Elimination System (NPDES). In Massachusetts, NPDES is jointly administered by the USEPA and the Massachusetts Department of Environmental Protection (MADEP). This program requires municipalities to submit periodic permits summarizing actions taken to manage stormwater and associated pollution. Activities such as good housekeeping and public outreach are required. The City of Somerville, as a municipality that operates a stormwater collection system, is subject to these regulations and submits regular reports (Somerville, 2010). Within Somerville, drainage is managed by the Department of Public Works (DPW). Their regulations require review of stormwater permits for new development and no specific changes to stormwater management for existing development. Stormwater funding comes from the general tax revenue allocated to the DPW. This is consistent with the Commonwealth of Massachusetts Stormwater Management Standards that require peak reduction, infiltration, and treatment of stormwater at new large developments. A new development, planned adjacent to the Winter Hill neighborhood at Assembly Square, also falls under these standards.

In addition, Somerville has developed an "Environmental Strategic Plan," in order to make a "long-term commitment to sustainability and environmental stewardship" (Somerville, 2007). In the plan, among many other environmental management and adaptation measures, stormwater management is discussed in connection with water quality in the Mystic River. While most of the stormwater projects mentioned are required under the NPDES program (Somerville, 2010), 
the Strategic Plan as a whole sets a tone in the City that environmental issues are important to residential quality of life and business development.

\subsection{Stakeholder Assessment}

As discussed above, individualstakeholders, including citizens, businesses and other organizations, are necessary participants in stormwater management action. Theirawareness of community stormwater problemsas well as their willingness to contribute to the community good is akey factor of sustainable stormwater management. To assess these characteristics, in 2009 we conducted interviews of a wide range of people, including representatives from local, state and federal agencies, local non-profits and non-governmental organizations, and residents of the targeted neighborhood. The interviews took place with either one or two team members, and from one to three interviewees from the same organization or neighborhood. We conducted our interviews as researchers affiliated with academic organizations, without the presence of any representative of the city. The Massachusetts Institute of Technology's Institutional Review Board (IRB) approved the interview process.

The interviews followed a general guideline of questions (such as shown in Table 1), adjusteddepending upon the interviewee. Due to time constraints, we planned our questions to cover all of the main issues within a single interview. Interviews aimed at understanding the potential role of respondents in provision of a stormwater management public good and the benefits he or she might expect from such public good. Interviews started with a brief description of the research project, and included discussion of:

- Role of the interviewee or of the interviewee's organization/employer in stormwater education or management (if applicable),

- Attitudes around climate change,

- Knowledge of Low Impact Development (LID) management techniques, and,

- Perceptions of obstacles and incentives to implement LID, particularly as an adaptation measure.

These topics are expected to provide information on each interviewees' perception of their stakes in stormwater issues as well as of local salience of stormwater management issues. They inform researchers about interviewees' understanding of stormwater management with LIDs, their capacity to influence others' understanding, and their appraisal of expected efficiency. The interviews were tailored to inform on stakeholders' willingness to contribute to provision of stormwater management public good through individual behavioral patterns at the level of their own land or the land they or their institution manages.

All questions for the residents were open-ended, and included questions in four categories:

- Yard paving attitudes (i.e. If you have paved your yard, why did you do so? If you have not chosen to pave your yard, why not? Approximately what portion of your neighbors have paved their yards? Do you have a sense of the reasons they might have done so?)

- Public LID techniques (i.e. Are you aware of city programs for managing stormwater? Does the city do a good job in managing stormwater now? Would you be willing to pay more to support additional/improved stormwater management techniques in town?) 
- Private LID techniques (i.e. Do you have a sump pump? Where does it discharge and how often? How willing are you to take responsibility for flooding inside your home? Is the city responsible if your basement floods? Or do you feel enough share in responsibility to clear up the problem on your own? If, during a rainstorm, a plastic bag was blocking a stormwater inlet, would you remove the bag?)

- General environmental attitudes (i.e. Would you be willing to pay a little every year for a better SWM or would you rather pay more for repairs in case of a catastrophic event occurrence, such as road washout, flooded basements? Do you believe that additional developments in the watershed would increase your flood risk? Would you rather pay flood insurance then pay a small amount each year for improved SWM?

Questions for agencies and NGOs were also open-ended. These questions included: What do you remember about a recent flooding event? What environmental initiatives is the City administering and how effective are these programs? How does your agency support local open space? How does your agency work towards reduction of local climate change impact? Are there any institutional barriers to improved stormwater management? How are LIDs viewed within your agency in particular?

Interviews were meant as discussions, respondents providing explanations and stories about their experiences.Interviews closed with a request for suggestions of other stakeholders and/or decision makers to interview. This "snowball" approach enlarged the pool of interviewees and the range of perspectives that werecollected.The first interview was with Somerville's city administrator in charge of environmental issues who helped define and contact a first cadre of interviewees. Although this could create bias in theinterviewee sample, this approach had two main advantages. First, it gave us social and political recognition; having an initial introduction from the local government "opened doors" and made some interviewees feel more able to respond. Second, it provided us with an initial list of NGOs who were concerned and active.

We also conducted informal interviews of case study neighborhood residents using a transect method: two researchers walked through the neighborhood on three different days, asking people encountered questions about flood issues and climate change in their neighborhood. The method provided a broad range of views from residents; some intervieweesaddressed only a subset of the questions, for instance if they were hurrying to work.

Our final sample included interviews with six city government representatives, six representatives from the federal and state level, nine representatives from local NGOs, and twenty individual residents. The numbers provided diversity of viewpoints, but are insufficient to conduct any statistical analysis.

Interviewees were classified into four participant types: residents, non-governmental organizations, city government/agencies, and state/federal government agencies. Interviewees at the state and federal levels were grouped due to low numbers of interviews. Wheninterviewees fell into more than one category, comments were considered according to context. An NGO director's comments about personal property within the target neighborhood, for example, were considered with residents' perceptions. Interview responses were grouped into issue areas, such asperception of climate change/adaptation, flooding, and low impact development techniques. 
Surveyresults are summarized in Table2. In general, most intervieweesare concerned about climate change andhave observed stormwater flooding. The majority feel positively towards LIDs, which have co-benefits beyond climate change. Table 3 summarizes these views as "Here and Now" or "Prepare and Monitor" as described above in Section 1.3. While residents and City employees seem to remain a bit conservative on action, NGOs and state or federal actors tend to lean towards action.

\subsubsection{Perceptions of Climate Change and Adaptation}

Each response was categorized as "low," "medium," or "high" for concern about climate change and adaptation. A "low" climate change and adaptation ranking was assigned to individuals who did not expect specific impacts of climate change in Somerville and/or did not expect any significant impacts within a generation. A "medium" ranking was assigned if the interviewee described specific climate change impacts anticipated for Somerville and/or expected significant impacts within a generation. "Medium" ranked individuals did not make any evident adaptations in anticipation of changed climactic conditions. A "high" climate change and adaptation ranking was assigned to individuals like those ranked "medium," but who also indicated change in behavior to adapt to climate change. Climate change mitigation actions, such as driving less, were not considered sufficient to achieve a "high" climate change ranking. "No data" indicates that a particular question was not asked of that interviewee due to time or other constraints.

A substantial majority (more than 70\%) of interviewees in all categories believe climate change will have measurable impact on their community within a generation. No interviewees challenged the assertion that climate change will increase the frequency and intensity of rainfall events. The study, however, found little evidence of adaptation-changes in stormwater practice or policy in response to the perceived threat of climate change. As a state official remarked, "Climate change is not being considered anywhere in stormwater management." An initial finding, therefore, is that a shared perception of the reality of climate change is not in itself sufficient to produce a change in stormwater practice.

The study revealed significant variations in perception of climate change between categories of interviewees.

Residents expressed a general sense of disempowerment around altering the course of climate change. "It's happening, but it's hard to make change," remarked one resident, adding "[change] takes everyone doing something." Similarly, several individuals expressed the perception that responsibility for addressing climate change lies with national policy makers. As one resident succinctly explained, "If the government doesn't do something, we're screwed." This attitude shows that some residents perceive their scope of action at the level of handling the consequences of change, not acting at the cause level. As far as stormwater management is concerned, LIDs are still qualified since they are specifically tailored to be efficient at this level.

City officials alsoseem to consider the primary onus of climate change adaptation as lying beyond their own responsibility. One interviewee, for example, described the City's best approach to adaptation as: "Do what we can, and hope that the national and international political actors address it." Another expressed hopes that "stormwater experts" were devising adaptive stormwater management systems adequate to meet the needs of changed climactic conditions, saying the "whole engineering profession has to look at it." A third City employee echoed this 
sentiment, "As long as engineering firms aren't changing their strategies, nothing is going to change. Climate change adaptation has not gone deep into the psyche of engineers."

NGO representativeswere most proactive around climate change adaptation with $77 \%$ (seven out of nine) indicating some changed action towards climate adaptation. This was expected as NGOs were selected for interviews based on their aligned interest with the study area. More notable, therefore, were their perceptions of their constituents and the City. Referring to the City's many new immigrants, one NGO official described a lack of awareness of climate change and general environmental issuesdue to limited English skills, "they have heard about things vaguely." This same interviewee noted that many adult immigrants work two jobs to support families, and focus mainly on "basic survival. Issues of climate change are not as important as putting food on the table." Most NGO interviewees expressed similar skepticism about the general public's awareness of climate change threats to the city. This view agrees with our findings that residents are generally not implementing climate change adaptations. One NGO representative noted that since the Gulf Coast devastation following Hurricane Katrina, many individuals are taking climate change more seriously. "Enough alarm bells are going off....More and more people get it."

NGO perceptions of the City's approach to climate change were moderately favorable. Nearly all interviewees described the City's interest in making Somerville "green." "The mayor gets that there's a lot of potential to be a sustainable city." This same interviewee noted, however, that "there's so much more that they could do," a sentiment echoed by three others interviewed. When asked what the City do to better adapt to climate change, interviewees described more stringent design requirements for new developments and better incentives for individuals and developers to install LIDs. One interviewee explained that it was difficult for the City to garner momentum to adapt stormwater management practice to climate change because intense storms are episodic; concern over flooding wanes and political pressure dissipatesas time since an intense storm increases.

As with NGOs, state and federal officials were selected for interviews based on expertise or jurisdiction over environmental issues. These interviewees' awareness of and concern about climate change adaptation may be biased toward higher levels of concern. One individual in this category seemed to summarize all of the interviews, describing work on climate change adaptation as "really just beginning." Interviewees in this category report that efforts to implement effective climate change mitigation planning seem haphazard, conducted through informal networks by staff motivated by the topic rather than through formal administrative hierarchies. As an EPA Region 1 employee commented, "we don't even have one full time climate change person, and we've been ahead of the rest of the regions on climate change." When asked what kind of action was most needed, this interviewee described the need to incorporate a climate change framework into all areas of the agency's work. Other needs outlined included sharing climate change science with communities in ways that are "understandable, not paralyzing," and providing communities with tools to understand their own vulnerabilities and incorporate that understanding into planning. As discussed above in Section 1.3 , these responses are "here and now,"not "monitor and wait."

Perceptions of climate change and adaptation converge towards a belief that the importance of stormwater managementand the need for adaptation are both growing. Even though no clues were given at this level on how to solve the social dilemma of distributed stormwater 
management, interviewees mostly agree that the need to invest in this public good current and growing.

\subsubsection{Awareness of Flooding}

An interviewee who could describe a specific flood event was assessed as flood aware; those who could not were assessed as unaware. If specific flood events were not covered in an interview, "no data" were assigned. A majority of residents interviewed (11 of 15 asked) have experienced flooding either in basements or at the street level. Though not explicitly measured, residents seemed to have a generally sophisticated understanding of causes of flooding. Residents referenced sewer capacity, runoff from paved surfaces, age of the infrastructure, operation of the Amelia Earhart Dam's floodgate, and impact of building on fill as contributors to problems with flooding. For residents, flooding is generally accepted as an inevitable and recurring condition in Somerville, seeming to cause moderate inconvenience rather than significant hardship. Relatively high numbers of individuals in other categories also reported having observed flooding in Somerville [City officials (86\%) and NGOs (88\%)]. Such moderate vulnerability shows that the initial salience of stormwater management is rated rather low among the interviewees. Involvement in a collective action to provide this public good is hence more difficult to achieve. This raises the need for concerned action groups to be involved in educating the public and in getting people involved in a collective action process.

\subsubsection{Resident Attitudes toward LIDs/Stormwater management}

Responses were ranked for perceptions around LIDs (proactive, positive, neutral, mixed, or negative). A "proactive" ranking refers to interviewees who had taken a clear action to increase LID usage (e.g. a resident installing a rain barrel; passing stormwater regulations to require LID). A "positive" ranking refers to interviewees who indicated a generally favorable perception of LIDs but had not taken any action to increase LID usage. An individual who expressed a perception toward LIDs that was neither positive nor negative was assigned a "neutral" rating. Those that indicated a positive perception about particular LIDs but negative perceptions about others were classified as "mixed." Individuals who expressed only negative perceptions about LIDs were assigned a "negative" ranking.

Residents' responses related to LIDs varied significantly, and should be considered with respect to the specific type of LID, rather than LIDs generally. Discussion of specific LIDs follows.

3.2.3.1 Paved yards and permeable surfaces - Yard pavingto provide additional parking or the convenience of reduced yard maintenance is a wide spread practice in Somerville, with many small parcels completely asphalted. This reduces the already small amount of pervious surface available for infiltration, increasing the volume of runoff to be managed in the collection system.

We did not interview any homeowner who had paved over their yard. We did, however, talk to several residents who commented on their neighbors' decision to pave yards, and one resident who had considered yard paving. Two residents explicitly linked the decision to pave with a subsequent increase in stormwater management problems, one describing her neighbor's increase in basement flooding after he paved over his yard. In contrast, another noted that for some homeowners, a paved yard could actually alleviate flooding, causing water to flow away from the individual's property, out of the homeowner's concern. 
Two residents with gardens described an explicit decision not to pave in order to retain space for growing vegetables. We observed many food gardens throughout the study area, and residents described an economic incentive to grow food: "food prices are high; it's much cheaper if I grow my own."

One resident had installed pervious pavers on his property to handle stormwater runoff, and another was considering doing so. For both individuals, the decision to install LIDs seemed to focus on the potential for improvements to their own property. However it remains a limited path to convince people to contribute because direct improvements are rather rarer than costs and constraints induced. The first interviewee installed extensive LIDs, including brick pavers and a perforated pipe through gravel, as part of a renovation to create patio space for entertaining guests. This man spoke quite knowledgeably about climate change and stormwater infiltration. The second was considering resurfacing his driveway with gravel to better infiltrate water discharged from his basement sump pump.

3.2.3.2 Green roofs- Although some residents needed prompting to understand what was meant by "green roof", residents expressed a generally favorable perception of the concept. When asked for a reaction to the possibility of a green roof on City Hall, one resident responded, "Great! We should use every square inch, and there's lots of square footage there. Green roofs help keep things cool, and reduce the heat island effect." Another resident described a favorable perception of the green roof on a newly built public school, citing educational opportunities as well as environmental benefits. The only objection raised to green roofs on public buildings was related to cost: "In a good economy, that's great, but otherwise the City should have other priorities." This same resident commented that the City should target large private developments which have more resources for green roof installation, referencing the new commercial development in Assembly Square and the new grocery store in her neighborhood.

When asked about converting their own roofs, residents offered mixed responses. One seriously considered installing a green roof over his new addition, but decided the cost was too high and the impact would be too low ("my ten foot by ten foot roof won't make much of a difference"). Others reported that they rent their property, and therefore could not make a drastic change. Here the limits of current institutional frame are pointed out.The people that could benefit from the development of LIDs are not those who have to invest. This also indicates the difficulty of understanding costs and benefits under the current frame. Overall, when all impacts are considered, the neighborhood-wide benefits may exceed the costs potentially incurred by the home owner, but there is no framework to understand, communicate, or share these costs.

3.2.3.3 Ponds-Few residents expressed an opinion about rainwater retention ponds. Three expressed skepticism, describing concerns about mosquitoes and loss of park space, and questioning the efficacy of a small pond. One resident was enthusiastic about the potential for a pond in a large public park, though he noted that he rarely visits the park himself and would not be impacted by any negative effects.

3.2.3.4 Rain barrels- The City of Somerville offers a discount on rain barrel purchase to residents. We did not encounter any residents who had taken advantage of this program, although the majority reported familiarity with the program. One resident had considered installing a rain barrel, but said his wife did not approve of the expenditure so the rain barrel was not purchased. Another resident indicated his neighbor hadinstalled a rain barrel, 
however,researchers did not see any such rain barrel at the indicated property. A third resident reported that, even with the discount, the benefits of a rain barrel are not worth the cost. This again raises the issue of cost benefit analysis available to stakeholders. Demonstration of added value at the level of the community could be a way to better appraise this cost benefit ratio and communicate it to stakeholders.

\subsubsection{Governmental and NGO Views of LID}

City officials described the City's rain barrel subsidy program as growing significantly in popularity, selling just 25 barrels when the program began three years ago, and today selling almost thatnumbereach week. Though some interviewees referred to the City's interest in green roofs, such as a potential to install a green roof on City Hall and recent incorporation of a green roof on a new public school, we did not talk to any City official with specific knowledge of either of these projects.

The active NGO community in Somerville plays a significant role in advocating for adoption of LIDs, for example negotiating with the Assembly Square developer for increased on-site infiltration and a green roof on the new Ikea store, encouraging green roof installations at businesses, helping acquire new greenspace for community gardens, and using rain barrels and pervious pavers in manyprojects. NGOs' perceptions of LIDs generally are, not surprisingly, very favorable, though some expressed disappointment that more LIDs are not implemented. NGOs are then good candidates to act as the boundary workers (McGreavy et al., 2013; Moss et al., 2009; Hoppe, 2010; Barreteau et al., 2012), or improved communication channels across and among groups, for example, able to increase landowners' understanding of suitability of LID development to provide flood protection.

State and federal interviewees' perception of LIDs is generally favorable, though LID implementation is described as needing additional attention to encourage or require communities to maximize use of LIDs. An EPA employee, for example, described a need to create a toolbox of scalable LID projects to aid communities. A state official described the potential for large scale demonstration projects to help tip behavior toward rapid adoption of LID's, stating that "In a development like Assembly Square, they could do so much, like showcase raingardens or pervious pavement. This would play a big role in education." Ironically, the state seems more tentative about implementing LIDs on its own urban properties. "Do you really want to recharge groundwater in a city situation?" asked one state employee, "With basement flooding in an urban area, people's attitude is 'get [the water] out of here."'

\subsubsection{Incentives and Barriers to LID for Adaptation}

Several perceived barriers emerged repeatedly through interviews helping to explain the difficulty in adapting stormwater management in general to climate change. In addition to the management constraints under existing conditions, such as the lack of clear authority for stormwater management and the sometimes invisible nature of the problem ("It goes down a pipe, literally out of sight, out of mind."), most frequently cited constraints were economic concerns, ranging from the City's weak tax base to individual costs for property improvements to the generally poor economy. One state official distinguished between stormwater management and water/sewer services: "Stormwater is a set of infrastructure with no revenue streams attached to it.Therefore it is easy to neglect, and is underfunded." This is another example of the current 
institutional frame's misfit for suitable handling of stormwater management. City interviewees were most influenced by costs and by constituent interests ("Boston has a lot of money. Poorer cities like Somerville, Everett and Malden will need Federal money to help us adapt").

Also, interviewees across categories expressed a perception that the potentialeffective responses to climate change are dwarfed by the scale of the problem. Responses ranged from deliberate avoidance ("There is some danger of looking at it [climate change adaptation] too squarely because the long-view is very alarming") to struggles to understand concrete impacts ("Science on climate change comes in every day like a fire hose. It's difficult to make sense of it and extract what's useful.").

State and federal interviewees seemed most sensitive to the potential for negative publicity, and perhaps preferred to err on the side of non-action. One interviewee described the State's calculation when considering newpolicy, "If we're doing something-like flood proofing to a higher elevation-should we do it subtly differently to reduce the chance of a problem in the media?"

Despite the existence of substantial barriers, many interviewees described incentives or drivers that could prompt implementation of adaptation, particularly for LID. These include awareness of climate change and acceptance of LIDs, agitation inside and outside of stakeholder groups, anactive NGO community committed to sustainability,leadership of individuals in decisionmaking positions, successful models potentially including implementation of LID in the new Assembly Square Mall redevelopment, and anticipated regulation and financial incentives. Quantification of risks in economic termsand clearer science would also be helpful. The lack of open space in Somerville is seen as both barrier and incentive - a barrier,because space is needed for some LIDs, andan incentive, because LIDs may create more open space,potentially easing Somerville's high level of imperviousness.

\section{Potential for LID as Part of an Adaptation Strategy for Stormwater Management in Somerville}

Distribution of provision of flood protection within a watershed among multiple landowners is potentially a new way to handle stormwater management, providing opportunities to overcome the financial and structural limits of stormwater management based on major collective infrastructures such as an oversized drainage network. However, LID implementation reinforces stormwater management's characteristics of a social dilemma. We investigated the potential to deal with this through a specific case study on the basis of local stakeholders' interviews, as a typical situation of distributed provision of stormwater management.

\subsection{Challenges to Solve the Stormwater Management Social Dilemma in Somerville}

The Winter Hill area of Somerville faces challenges in implementing LID as an adaptation strategy to expected increase of runoff-induced floods. It is densely populated, almost fully developed with small lot sizes and little potential for redevelopment. Somerville has little open space, high percentage of low pervious surfaces, and combined sewers. It has limited funding from general revenues, management must compete with potentially more pressing issues in the City Department of Public Works. There are multiple agencies at different levels of government involved in stormwater management. 
Somerville faces hence an acute social dilemma for providing secure stormwater management, that is difficult to fully resolve under current conditions. However analyzing opinions of local stakeholders reveals both the difficulties, and the potential for improved management. Difficulties are somewhat due to attributes of the community, but mainly due to the configuration of the stormwater management action arena (Ostrom, 2005), if not its mere absence. There is currently no local community of stormwater management, nor any rules in use. A fortiori, no institution fitting the contours of the set of concerned people, with its own source of revenues is in charge of this issue. Facilitating the emergence of such an action arena, at a suitable scale and with suitable participants is a prerequisite for local institutions in order to sort out the stormwater management dilemma.

The identification of suitable participants is a second issue. Interviews bring to the forefront the necessity to include landowner rather than resident, as renters are not permitted to act structurally on the land or on the house. However landowners happen to be more difficult to reach because they live elsewhere and will not directly benefit from their investment. Attributes of community are a clear handicap in Somerville: lack of financial means, high level of renting among inhabitants, and a large migrant population.

While most residents interviewed were reasonably knowledgeableof LID issues, thismay not be true for the immigrant population in Winter Hill. Recent reviews have shown that some negative impact of migration on resolving social dilemmasmay bein part due to the low social integration in the place of arrival (Curran and Agardy, 2004; Rudel, 2011). Building new institutions for a more sustainable stormwater management may not only reduce flooding, but may also bridgegaps in social bonds and education. This is an urgent task in Somerville in order to change the institutional frame of stormwater management.

\subsection{Some Real Assets to EncourageInnovation in Stormwater Management}

Beyond these difficulties, Somerville features other positive signs: increasing awareness of stormwater management, redevelopment opportunities, and presence of local NGOs to facilitate knowledge transfer between local authorities and local stakeholders.

Most interviewees, from residents to the Mayor, representatives of the City administration and the government of the Commonwealth of Massachusetts,areaware of climate change and support both adaptation and mitigation measures. Even though the issue of stormwater is not perceived as acute now, its trend appears to be worsening. This makes the issue of stormwater management more salient, motivating potential participants in an action arena related to solving this social dilemma. Salience impacts mental representations and the perceived scope of possible actions (Ostrom, 2005).At an administrative management level, there appears to be support for LID to manage climate change as well as more pressing present stresses

A second positive characteristic met in Somerville is the opportunity for a redevelopment area, in Assembly Square, with a possibility for experimentation and demonstration.Natural experiments as a way of testing and tuning social innovations are increasingly popular(Callon and Muniesa, 2006). Beyond the simple benefit ofimplementation within the whole complexity of a real-life situation, a natural experiment becomes also part of a social learning process. As far as LIDs and stormwater management are concerned, these experiments would allow (i) checking of assumptions of feasibility and efficiency, and (ii) demonstrating for local landowners and 
residents the suitability of implementing LIDs. While not overly large and not specifically designed for a changed climate, LIDs tested in Assembly squarewill help create further interest and demonstrate the feasibility of including innovative stormwater management in new local developments, in order to change mental representations of participants in this action arena. This opportunity gives potential for implementing adaptive stormwater management (Folke et al., 2005)cautiously and demonstratively.

Finally, NGOs could improve the possibility of change through raising the salienceof the stormwater management issue for residents and strengthening social bonding within community. The interviews showed that NGOs are deeply committed to both climate change and adaptationmanagement at the community level.Education outreach could first explainLIDs at the household level, in particular topreventpaving or to increaseunpaving/depaving of yards. Raising salience could accomplish a change of perspective on stormwater from a nuisance to a valued resource (Brown, 2005). This would change the format of the game, making contributions to stormwater management a publicgood that generates immediate private benefits to the contributors. Strengthening social links within the heterogeneous population of Winter Hillis another task for NGOs.Stronger bonds within community increase commitment to the common good and facilitate dissemination of information about LIDs techniques and benefits through word of mouth.

\subsection{Conclusion}

This paper described institutional and individual challenges to low impact development (LID) as an adaptation strategy for climate change from both literature and case study perspectives. LID was found to be favorable as an adaptation strategy because it is distributed, flexible, modular, and scalable. These characteristics make it possible to envision solving the social dilemma of providing efficient protection to stormwater flooding with institutional solutions on the basis of current knowledge on public good provision.

Individual contributions to the public good are possible for each local resident or stakeholder by implementing a LID at his/her own level. Emergence of a specific polycentric institutional setting empowering these contributions, facilitating group interaction at a very local level, and paving the way for efficient communication between households and policy makers is a condition for an efficient development of stormwater management through LIDs. Hence a polycentric governance system (Ostrom, 1999) could enable action towards stormwater management as early as possible, before it crosses thresholds meaning pollution impacts or even higher risk for citizens in low places. Neighborhood communities, municipalities and larger administrations can respectively communicate with landholders, facilitate LID siting through financial help, demonstration projects, and provision of suitable norms.

Interviews at various action levels in Somerville show that despite some existing barriers, such as lack of clear delineated boundaries and nested management organizations, several conditions for the emergence of such institutional settingshave already been met, including a stated readiness for action at many levels of government. Outreach and empowerment of residents to develop and maintain LID is ongoing through the work of government agencies and NGOs. Increasing communication between actors may improve education dissemination. However, it is apparent that the shared perception of the reality of climate change is not itself sufficient to 
produce a change in stormwater practice, when starting with a too low perceived importance of the issue.

Other dense, urban cities like Somerville around the world should consider addressing their own stormwater management framework as a social dilemma. Empowering residents to manage their own stormwater locally, accepting both the costs and the benefits of doing so, is a crucial step towards proactive adaptive management of stormwater for a changed climate. Even though all remains to be implemented, Somerville showcases that in difficult situations (low salience, changing population, low ratio of landowner-residents,...) identifyingpotentially acceptable factors of change among participants is important to envisage possible paths towards solution for the stormwater management social dilemma.

\subsection{Acknowledgements}

The authors wish to thank the National Oceanic and Atmospheric Administration Sectoral Applications Research Program, the City of Somerville and in particular Vithal Deshpande, the residents of Somerville willing to be interviewed, and Herman Karl.

\subsection{References}

Adger, N., Arnell, N.W., and E.L. Tompkins. 2005. Successful adaptation to climate change across scales. Global Environmental Change. 15(2) 77-86.

American City \& County (No author given). 2007. Stormwater utilities: Outreach a priority. American City and County. 122(13):10.

ASCE, 2013. "2013 Reportcard for America's Infrastructure.” American Society of Civil Engineers. Available at http://www.infrastructurereportcard.org.

Ashley, R.M. Balmforth, D.J., Saul, A.J., Blanskby, J.D. 2005. Flooding in the future Predicting climate change, risks and responses in urban areas Water Science \& Technology 52, 265-273.

Barreteau, O., Abrami, G., Daré, W. S., Du Toit, D., Ferrand, N., Garin, P., Souchere, V., Popova, A., Werey, C. 2012. Collaborative modelling as a boundary institution to handle institutional complexities in water management. In Restoring Lands-Coordinating Science, Politics and Action (pp. 109-127). Springer Netherlands.

Bates, B.C., Kundzewicz, Z.W., Wu, Z., Palutikof, J.P., 2008. Climate Change and Water. Geneva: Technical Paper of the Intergovernmental Panel on Climate Change. IPCC Secretariat.

Blomquist, W. 2001. Dividing the Waters: Governing Groundwater in Southern California. ICS Press, San Francisco, CA, USA.

Bosello, F., Nicholls, R.J., Richards, J., Roson, R., Tol, R. S. 2012. Economic impacts of climate change in Europe: sea-level rise. Climatic Change, 112(1), 63-81.

Bowen, G.N. 2003. A drain on the budget. Am. City County, 118(3), 30-32.

Brekke, L.D., Kiang, J.E., Olsen, J.R., Pulwarty, R.S., Raff, D.A., Turnipseed, D.P., Webb, R.S., White, K.D. 2009. Climate change and water resources management: A Federal perspective. Circular 1331. Reston: US Department of the Interior, US Geological Survey. Available at: http://www.usgs.gov/pubprod

Brisman, A. 2001. Considerations in establishing a stormwater utility. S. Ill. ULJ, 26, 505. 
Author-produced version of the article published in Journal of Water Resources Planning and Management-ASCE, 2015, N¹41(6), p. 04014080-1-04014080-13

Brown, R. 2005. Impediments to Integrated Urban Stormwater Management: The Need for Institutional Reform. Environmental Management 36, 455-468.

Callon, M., Muniesa, F., 2006. Economic Experiments and the Construction of Markets. In: MacKenzie, D., Muniesa, F., Siu, L. (Eds.), Performing Economics: How Markets Are Constructed. Princeton University Press, Princeton.

CDM. 1974. City of Somerville, Massachusetts: Report on Improvements to the Sewer System. $140 \mathrm{p}$.

Cettner, A., Ashley, R., Viklander, M., Nilsson, K. 2013. Stormwater management and urban planning: Lessons from 40 years of innovation. Journal of Environmental Planning and Management 56, 786-801.

CNN. 2010. " Heavy rains cause flash floods in greater Boston area" Available from: http://www.cnn.com/2010/US/07/10/massachusetts.flooding/index.html?iref=allsearch

Code Général des Collectivités Territoriales (CGCT). (2011).Articles L 2333-97 to L 2333-101: Possible actions for local governments; Decree no. 2011-815: Enforcement, 6 July 2011.

Curran, S., Agardy, T. 2004. Considering Migration and its effects on coastal ecosystems. In: Unruhl, J.D., Krol, M.S., Kliot, N. (Eds.), Environmental change and its implications for population migration. Kluwer, Dordrecht, Netherlands, pp. 201-229.

Deshpande, V., Roden, B. 2005. Stormwater Asset Management Using GIS. Presented at the Environmental Expo \& Conference, Boston MA. Slides at: http://www.slideshare.net/vvdeshpande/stormwater-asset-management-using-gis-v5

Douglas, E., Kirshen, P., Li, V., Watson, C., Wormser, J. 2013. "Preparing for the Rising Tide" Environmental, Earth, and Ocean Sciences Faculty Publication Series. Paper 3. Available at: http://scholarworks.umb.edu/envsty_faculty_pubs/3

Folke, C., Hahn, T., Olsson, P., Norberg, J. 2005. Adaptive Governance of Social-Ecological Systems. Annual Review of Environment and Resources 30, 441-473.

Greenaway, A., Allen, W., Feeney, C., Heslop, V. 2006. Learning into a Low-impact Future: Collaborative Approaches to Stormwater Management. New Zealand WWA Conference on Stormwater Management.

Grimm, N.B., Foster, D., Groffman, P., Grove, J.M., Hopkinson, C.S., Nadelhoffer, K.J., Pataki, D.E. \& Peters, D.P. (2008). The changing landscape: ecosystem responses to urbanization and pollution across climatic and societal gradients. Frontiers in Ecology and the Environment, 6(5), 264-272.

Hamin, E.M., Gurran, N. 2009. Urban form and climate change: Balancing adaptation and mitigation in the U.S. and Australia. Habitat International 33, 238-245.

Hardy, S.D., Koontz, T.M. 2010. Collaborative watershed partnerships in urban and rural areas: Different pathways to success? Landsape and Urban Planning 95, 79-90.

Hoppe, R. 2010. "Lost in translation? A boundary work perspective on making climate change governable." 109-130.

Janssen, M., Ahn, T.K. 2006. Learning, Signaling, and Social Preferences in Public-Good Games. Ecology and Society 11, 21.

Kharin, V.V., Zwiers, F.W., Zhang, X., Hegerl, G.C. 2007. Changes in temperature and precipitation extremes in the IPCC ensemble of global coupled model simulations, J. Climate, 20, 1419-1444.

Kirshen, P., Watson, C., Douglas, E., Gontz, A., Lee, J., Tian, Y. 2008. Coastal flooding in the Northeastern United States due to climate change.Mitigation and Adaptation Strategies for Global Change, 13(5-6), 437-451. 
Koo, D. H. D., Jung, J. K., Lee, W. 2012. Sustainability Applications for Storm Drainage Systems Minimizing Adverse Impacts of Global Climate Change. In ICPTT 2012@ sBetter Pipeline Infrastructure for a Better Life. 36-47. ASCE.

Kousky, C., Rostapshova, O., Toman, M., Zeckhauser, R. 2010. Responding to Threats of Climate Change Mega-Catastrophes. HKS Faculty Research Working Paper Series, RWP10-008, John F. Kennedy School of Government, Harvard University.

Lempert, RJ., Groves, D.G. 2010. Identifying and Evaluating Robust and Adaptive Policy Responses to Climate Change for Water Management Agencies in the American West. Technological Forecasting and Social Change 77, 960-974.

Massachusetts Energy and Environmental Affairs (MEEA). 2008. Massachusetts Stormwater Handbook. Available at: http://www.mass.gov/eea/agencies/massdep/water/ regulations/massachusetts-stormwater-handbook.html

McGreavy, B., Hutchins, K., Smith, H., Lindenfeld, L., Silka, L. 2013. Addressing the Complexities of Boundary Work in Sustainability Science through Communication. Sustainability, 5(10), 4195-4221.

Mees, H.L.P., Driessen, P.P.J., Runhaar, H.A.C., Stamatelos, J. 2013. Who governs climate adaptation? Getting green roofs for stormwater retention off the ground. Journal of Environmental Planning and Management 56, 802-825.

Metcalf \& Eddy, Inc., Tchobanoglous, G., Burton, F.L., Stensel, H.D. 2002. Wastewater engineering: treatment and reuse, 4th edition, McGraw-Hill Publishing, USA.I

Milly, P.C.D., Betancourt, J., Falkenmark, M. 2008. Climate Change: Stationarity is Dead: Whither Water Management? Science, 319(5862), 573-574.

Morison, P.J., Brown, R.R. 2011. Understanding the nature of publics and local policy commitment to Water Sensitive Urban Design. Landsape and Urban Planning 99, 83-92.

Moss, T., Medd, W., Guy, S., Marvin, S. 2009. Organising Water: The Hidden Role of Intermediary Work. Water Alternatives, 2(1).

Nakićenović, N., and Swart, R., ed., 2000. Special Report on Emissions Scenarios: A special report of Working Group III of the Intergovernmental Panel on Climate Change, Cambridge University Press,

National Academy of Engineering (NAE) 2009. Grand Challenges for Engineering. http://www.engineeringchallenges.org.

National Research Council (NRC). 2009. Urban Stormwater Management in the United States. Washington, DC: The National Academies Press.

Ostrom, E. 1990. Governing the commons: the evolutions of institutions for collective action. Cambridge University Press.

Ostrom, E. 1992. Crafting institutions for self governing irrigation systems. ICS Press, San Francisco.

Ostrom, E., 1999. Coping with Tragedies of the Commons. Annual Review of Political Science 2, 493-535.

Ostrom, E. 2005. Understanding Institutional Diversity. Princeton University Press, Princeton.

Ostrom, E., Gardner, R., Walker, J., 1994. Rules, Games and Common-Pool Resources. The University of Michigan Press, Ann Arbor, Michigan, USA.

Pahl-Wostl, C., Kabat, P., Möltgen, J. (Eds.), 2007. Adaptive and Integrated Water Management: Coping with Complexity and Uncertainty. Springer, Berlin, Germany. 
Author-produced version of the article published in Journal of Water Resources Planning and Management-ASCE, 2015, N¹41(6), p. 04014080-1-04014080-13 The original publication is available at http://ascelibrary.org

Doi: 10.1061/(ASCE)WR.1943-5452.0000476

Palmer, M.A., Reidy Liermann, C.A., Nilsson, C., Flörke, M., Alcamo, J., Lake, P.S., Bond, N. 2008. Climate change and the world's river basins: anticipating management options. Frontiers in Ecology and the Environment,6(2), 81-89.

Parkinson, J. 2003. Drainage and stormwater management strategies for low-income urban communities. Environment and Urbanization, 15(2), 115-126.

Powell, A. 2008. An Analysis of the Change of Design Storms due to Future Climate Predictions. MS Thesis, University of Colorado at Boulder Graduate School and the Civil, Environmental, and Architectural Engineering Department. 95p.

Redmond, W.H. 2003. Innovation, Diffusion, and Institutional Change. Journal of Economic Issues 37, 665-679.

Roseen, R.M., Ballestero, T.P., Houle, J.J., Briggs, J.F., Houle, K.M. (2011). Water quality and hydrologic performance of a porous asphalt pavement as a storm-water treatment strategy in a cold climate. Journal of Environmental Engineering, 138(1), 81-89.

Rudel, T.K. 2011. The commons and development: unanswered sociological questions. International Journal of The Commons 0.

Saravanapavan, T., Zhang, G.S., Voorhees, M. 2013. Sustainability through Optimization: The Future of Watershed Management. Applied Mechanics and Materials, 260, 876-881.

Sarker, A., Ross, H., Shrestha, K.K. 2008. A common-pool resource approach for water quality management: An Australian case study. Ecological Economics 68, 461-471.

Sell, J., Son, Y. 1997. Comparing Public Goods with Common Pool Resources: Three Experiments. Social Psychology Quaterly 60, 118-137.

Semadeni-Davies, A., Hernebring, C., Svensson, G., Gustafsson, L.G. 2008. The impacts of climate change and urbanisation on drainage in Helsingborg, Sweden: Combined sewer system. Journal of Hydrology, 350(1), 100-113.

Somerville, City of. Mayor's Office of Sustainability and Environment. 2007 Sustainable Somerville: An Environmental Strategic Plan.

Somerville, City of. Office of Strategic Planning and Community Development. 2009 "Trends in Somerville: Population Technical Report."

Somerville, City of. 2010 Somerville NPDES PII Small MS4 General Annual Report. EPA NPDES Permit Number MAR041082.

Stakhiv, E. Z. 2011. Pragmatic Approaches for Water Management Under Climate Change Uncertainty1. JAWRA Journal of the American Water Resources Association, 47(6), 1183-1196.

Torgler, B., Garcia-Valinas, M.A., Macintyre, A. 2008. Justifiability of Littering: An Empirical Investigation. FEEM Working Papers. FEEM, Venezia, Italy, p. 37.

United States Census Bureau. 2010. 2010 Census Data. Available: http://www.census.gov/

United States Census Bureau. 2010a. American Community Survey. Available at: http://www.census.gov/acs/www/.

United States Environmental Protection Agency (USEPA). (2012) National Pollutant Discharge Elimination System (NPDES) Stormwater Program. Available at: http://cfpub.epa.gov/npdes/home.cfm?program_id=6

United States Environmental Protection Agency (USEPA). (2013) Low Impact Development (LID) Factsheet. Updated: 21 October 2013. http://water.epa.gov/polwaste/green/

United States Global Change Research Program (USGCRP). 2009. Global Climate Change Impacts in the United States. T. R. Karl, J. M. Melillo, and T. C. Peterson,(eds.). Cambridge University Press. 
van de Meene, S.J., Brown, R.R., Farrelly, M.A. 2011. Towards understanding governance for sustainable urban water management. Global Environmental Change 21, 1117-1127.

Walsh, C.J., Fletcher, T.D., Burns, M.J. 2012. Urban Stormwater Runoff: A New Class of Environmental Flow Problem. PLOS one 7, e45814.

Water Environment Research Foundation (WERF). 2009. Implications of Climate Change for Adaptation by Wastewater and Stormwater Agencies. Climate Change Challenge. Prepared by Stratus Consulting Inc. and MWH Global Inc.

Wang, X., Shuster, W., Pal, C., Buchberger, S., Bonta, J., Avadhanula, K. 2010. Low Impact Development Design-Integrating Suitability Analysis and Site Planning for Reduction of Post-Development Stormwater Quantity. Sustainability 2, 2467-2482.

Welty, C., Miller, A.J., Belt, K.T., Smith, J.A., Band. L.E., Groffman, P.M., Scanlon, T.M., Warner, J., Ryan, R.J., Shedlock, R.J., McGuire, M.P. 2007. Design of an environmental field observatory for quantifying the urban water budget. In Cities of the Future towards Integrated Sustainable Water and Landscape. Novotny, V., Brown, P., Eds., IWA Publishing: London, UK. pp72-88.

Yohe, G. 2009. Toward an Integrated Framework Derived from a Risk-Management Approach to Climate Change: an Editorial Comment, Climatic Change 95: 325-339

Figure caption

Figure 1 - Study Area and Main Sewer Lines and Outfalls [Base Layer from Office of Geographic Information (MassGIS), Commonwealth of Massachusetts, Information Technology Division]

Table 1 - Sample Questions from Survey

\begin{tabular}{|c|c|}
\hline Group & Sample Questions \\
\hline Residents & $\begin{array}{l}\text { Approximately what part of your yard is paved? } \\
\qquad \begin{array}{r}\text { If you have paved your yard.... Why did you do so? } \\
\text { How much did it cost to pave the yard? } \\
\text { Can you think of any reasons you might want to "unpave"? } \\
\text { Do you believe that you are impacting in any way the water } \\
\text { quality and quantity aspects of Mystic River? } \\
\text { If you have not chosen to pave your yard, why not? } \\
\text { Approximately what portion of your neighbors have paved their yards? } \\
\text { Do you have a sense of the reasons they might have done so? }\end{array}\end{array}$ \\
\hline Officials & $\begin{array}{l}\text { What do you remember about a specific local flooding event in the past? } \\
\text { What City initiatives exist to address environmental issues? } \\
\text { What has worked well? Why? } \\
\text { What has not seemed to work well? Why not? } \\
\text { What still needs to be addressed? } \\
\text { Which groups have served as good partners for initiatives? }\end{array}$ \\
\hline
\end{tabular}


Table 2- Survey Results by Category

\begin{tabular}{|l|l|c|c|c|c|}
\hline & & \multicolumn{4}{|c|}{ Survey Respondent Category } \\
\hline Survey Response & & Resident & City & NGO & State/Fed \\
\hline Observed Flooding & Yes & $11(73 \%)$ & $6(86 \%)$ & $7(88 \%)$ & $3(100 \%)$ \\
\cline { 2 - 6 } & No & $4(27 \%)$ & $1(14 \%)$ & $1(12 \%)$ & $0(0 \%)$ \\
\cline { 2 - 6 } & No Data & 1 & 1 & 1 & 4 \\
\hline \multirow{5}{*}{ Climate Change Concern } & High & $1(11 \%)$ & $1(12 \%)$ & $7(78 \%)$ & $3(43 \%)$ \\
\cline { 2 - 6 } & Medium & $4(44 \%)$ & $4(50 \%)$ & $1(11 \%)$ & $4(57 \%)$ \\
\cline { 2 - 6 } & Low & $4(44 \%)$ & $3(38 \%)$ & $1(11 \%)$ & $0(0 \%)$ \\
\cline { 2 - 6 } & No Data & 9 & 0 & 0 & 0 \\
\hline \multirow{5}{*}{ LID Attitudes } & Proactive & $3(25 \%)$ & $2(33 \%)$ & $4(80 \%)$ & $4(67 \%)$ \\
\cline { 2 - 6 } & Positive & $2(17 \%)$ & $2(33 \%)$ & $0(0 \%)$ & $1(17 \%)$ \\
\cline { 2 - 6 } & Neutral & $3(25 \%)$ & $1(17 \%)$ & $1(20 \%)$ & $0(0 \%)$ \\
\cline { 2 - 6 } & Mixed & $2(17 \%)$ & $1(17 \%)$ & $0(0 \%)$ & $1(17 \%)$ \\
\cline { 2 - 6 } & Negative & $2(17 \%)$ & $0(0 \%)$ & $0(0 \%)$ & $0(0 \%)$ \\
\cline { 2 - 6 } & No Data & 6 & 2 & 4 & 1 \\
\hline
\end{tabular}

Table 3 - Perceived Readiness for Action by Category

\begin{tabular}{|l|l|l|l|l|l|}
\hline & & \multicolumn{4}{|l|}{ Survey Respondent Category } \\
\hline Response & Readiness & Resident & City & NGO & State/Fed \\
\hline \multirow{4}{*}{$\begin{array}{c}\text { Cimate } \\
\text { Change }\end{array}$} & Here and Now & $1(11 \%)$ & $1(12 \%)$ & $7(78 \%)$ & $3(43 \%)$ \\
\cline { 2 - 6 } & Prepare \& Monitor & $4(44 \%)$ & $4(50 \%)$ & $1(11 \%)$ & $4(57 \%)$ \\
\cline { 2 - 6 } & Uncertain & $4(44 \%)$ & $3(38 \%)$ & $1(11 \%)$ & $0(0 \%)$ \\
\cline { 2 - 6 } & No Data & 9 & 0 & 0 & 0 \\
\hline \multirow{4}{*}{ LID Attitudes } & Here and Now & $3(25 \%)$ & $2(33 \%)$ & $4(80 \%)$ & $4(67 \%)$ \\
\cline { 2 - 6 } & Prepare \& Monitor & $2(17 \%)$ & $2(33 \%)$ & $0(0 \%)$ & $1(17 \%)$ \\
\cline { 2 - 6 } & Uncertain & $7(59 \%)$ & $2(34 \%)$ & $1(20 \%)$ & $1(17 \%)$ \\
\cline { 2 - 6 } & No Data & 6 & 2 & 4 & 1 \\
\hline
\end{tabular}

